\title{
Original
}

\section{Detection of Nitric Oxide Generation by Electron Spin Resonance Spectroscopy after Partial Hepatectomy}

\author{
Keitaro Mitamura ${ }^{1)}$, Koji Otsuka ${ }^{1)}$, Hirohisa Kato ${ }^{1)}$, \\ Yuta ENAMI ${ }^{1)}$, Noriyuki Murai ${ }^{1)}$, Takashi NirYa', \\ Takeshi Aoki ${ }^{1)}$, Yoshinori Shimizu' ${ }^{1)}$, Kazue SATOH $^{2)}$, \\ Takashi Tobe $^{2)}$, Seiji ShIOda ${ }^{3)}$ and Mitsuo Kusano ${ }^{1)}$
}

\begin{abstract}
Nitric oxide $\left(\mathrm{NO}^{\circ}\right)$, a paramagnetic molecule, has a very short half-life of less than five seconds. The direct measurement of $\mathrm{NO}^{\circ}$ is therefore difficult and is not commonly performed. The liver is one of the organs in the body that is clearly influenced by $\mathrm{NO}^{*}$ which is generated in response to septic shock, portal hypertension and liver surgery such as, in the case presented here, partial hepatectomy. To detect time-dependent changes in NO after hepatectomy and regeneration of the liver, we used ex vivo electron spin resonance (ESR) spectroscopy by injection of an $N$-methyl-D-glucamine dithiocarbamate $(\mathrm{MGD})$ and $\mathrm{Fe}^{2+}$ complex $\left(\left[(\mathrm{MGD}){ }_{2} \mathrm{Fe}\right]\right)$. After injection of this complex, NO signals were detected by ESR in both regenerating and sham-operated livers. NO ${ }^{\circ}$ generation had increased significantly at $36 \mathrm{~h}$ and peaked at $72 \mathrm{~h}$ after partial hepatectomy. The expression of inducible nitric oxide (iNOS) mRNA was analyzed by real-time PCR and its maximum level was detected at $72 \mathrm{~h}$ after partial hepatectomy. These results indicate that NO-may play an important role in regulating liver regeneration after partial hepatectomy.
\end{abstract}

Key words : nitric oxide $\left(\mathrm{NO}^{\circ}\right)$, electron spin resonance (ESR), partial hepatectomy, liver regeneration, inducible nitric oxide (iNOS)

\section{Introduction}

Liver regeneration refers to the ability to restore liver mass and function after injury or partial hepatectomy. But the removed lobes or segments of this organ are usually not recovered. On the contrary, the restoration of the liver mass occurs with compensatory hyperplasia of the hepatocytes in the remaining lobes. In human liver partial transplantation, a mismatch of liver size often occurs after transplantation. Therefore, the liver has to regenerate sufficiently to fit the body ${ }^{1)}$ and to do this the liver needs to know when to initiate and when to cease regeneration. It is recognized that the portal blood flow plays a pivotal role in the process of restoration of the liver mass after partial hepatectomy ${ }^{2}$.

It has been recently demonstrated that the stress from an hepatectomy can induce gene

1) Department of Surgery, Division of General \& Gastroenterological Surgery, Showa University, School of Medicine, 1-5-8 Hatanodai Shinagawa-ku, Tokyo, 142-8666, Japan.

2) Department of Medicinal Information, Showa University, School of Pharmaceutical Science.

3) Department of Anatomy I, Showa University, School of Medicine, Tokyo, Japan and Core Research for Evolutional Science and Technology (CREST), Japan Science and Technology Corporation. 
expression of $c$-fos, $c$-myc, $c$-jun ${ }^{3)}$ and stimulate nitric oxide (NO') release ${ }^{4,5)}$ which is produced by nitric oxide synthase ${ }^{6)}$. These events may in turn trigger the liver regeneration cascade $^{5,7-9)}$. In addition to liver regeneration, $\mathrm{NO}^{\circ}$ protects surviving regenerated hepatocytes and induces tissue regeneration, as reported in transgenic inducible nitric oxide synthase (iNOS) deficient mice ${ }^{10)}$. Also, $\mathrm{NO}^{\circ}$ has been shown to play very important roles in the immediate action after partial hepatectomy. After partial hepatectomy, time dependent production of $\mathrm{NO}^{\circ}$ is observed. Obolenskaya et al $^{11)}$. have shown that there are three peaks of NO production after partial hepatectomy, the first peak is at $1 \mathrm{~h}$ after, the second peak is $4-12 \mathrm{~h}$ after and the third peak of $\mathrm{NO}^{\circ}$ production is detected at $30 \mathrm{~h}$ after the hepatectomy ${ }^{11)}$. Although $\mathrm{NO}^{\circ}$ is a relatively short-lived and somewhat reactive free radical ex vivo, direct detection of the generated $\mathrm{NO}^{-}$is demonstrated enzymatically ${ }^{11-14)}$. Komarov et $a l^{15)}$. and Lai and Komarov ${ }^{16)}$ have detected NO directly in lipopolysaccharideinduced shocked mice by the use of a $N$-methyl-D-glucamine dithiocarbamate (MGD) and $\mathrm{Fe}^{2+}$ complex. This ex vivo spin-trapping method is sensitive enough to detect micromolar NO levels produced by iNOS. iNOS has been detected and is readily up-regulated in the liver ${ }^{17)}$, this contributes to the inflammatory processes through high NO output. Cytokines have been demonstrated to regulate the expression level of iNOS ${ }^{18)}$.

In the present study we measured time-dependant changes of $\mathrm{NO}^{\circ}$ in the liver after partial hepatectomy ${ }^{19)}$ using an electron spin resonance (ESR) spectrometer. In addition, we also analyzed the time-dependant changes of iNOS mRNA expression by real time PCR in order to determine the function of iNOS during liver regeneration after partial hepatectomy.

\section{Materials and Methods}

\section{Animals and partial hepatectomy}

Male Balb/c mice between 8 and 10 weeks of age were supplied by Sankyo Labo Service Co. (Tokyo, Japan). Mice underwent a $70 \%$ partial hepatectomy according to the method of Higgins and Anderson ${ }^{19)}$. The partially hepatectomized and sham-operated mice were maintained at a stable depth of anesthesia with sevoflurane. Mice and all animal experiments in the present study were treated in accordance with guidelines outlined in the Animal Care and Use Committee of Showa University.

\section{Assay for radical intensity}

Mice were anesthetized with sodium pentobarbital and injected with $200 \mathrm{mM}$ N-MethylD-glucamine dithiocarbamate sodium salt (MGD ; Dojin Co., Kumamoto, Japan) and 200 $\mathrm{mM}$ ferrous sulfate $\left(\mathrm{FeSO}_{4}\right)$ complex ([3:1], $0.4 \mathrm{ml} / 20 \mathrm{~g}$ mice weight $)$ through the jugular vein 2 minutes before liver resection. Mice were sacrificed at 12, 24, 36, 48, 72, and $96 \mathrm{~h}$ after partial hepatectomy. Two groups of the mice which were sacrificed $72 \mathrm{~h}$ after the partial hepatectomy were injected with $N$-nitro-L-arginine methyl ester (L-NAME; Sigma Chemical Co., Ltd.) dissolved in the saline solution $(4 \mathrm{mg} / 20 \mathrm{~g}$ and $2 \mathrm{mg} / 20 \mathrm{~g}$ mice weight) intraperitoneally at $24 \mathrm{~h}$. Once sacrificed, a piece of the remnant right lobe $(43 \pm 3 \mathrm{mg})$ was compressed immediately on a Tissue cell and the level of NO measured by a ESR spectroscope (JEOL JES RE1X, X-band, $100 \mathrm{KHz}$ modulation frequency) at room temperature $\left(22^{\circ} \mathrm{C}\right)$. Instrument settings were as follows: center field, $330 \pm 5.0 \mathrm{mT}$; microwave power, $16 \mathrm{~mW}$; modulation amplitude, $0.5 \mathrm{mT}$; gain, 5000 ; time constant, $1 \mathrm{~s}$; scanning time, $8 \mathrm{~min}$. The ESR signal of the $\left[(\mathrm{MGD}){ }_{2} \mathrm{Fe}\right]-\mathrm{NO}$ complex gave a characteristic 3 peak spectrum, the 
height of first peak was measured as the ESR intensity.

\section{$R T-P C R$}

Total RNA was isolated from four regenerated remnant liver tissues, which were frozen at each time points after hepatectomy, using ISOGEN reagent according to the manufacture's instructions (NIPPON GENE, Toyama, Japan). The average RNA yield was approximately $1 \mu \mathrm{g}$ RNA/mg mouse liver tissue. Hybridization probes for real-time reverse transcription polymerase chain reaction (RT-PCR) analysis were created using the following gene specific primers and RT-PCR amplification: mouse iNOS: 251 bp-fragment (mouse iNOS forward: 5'-GCA AAC CCA AGG TCT ACG TT-3'; mouse iNOS reverse : 5'-GGA AAA GAC TGC ACC GAA GA -3'; hybridization probes: 5'-TGG TAG CCA CAT CC GAG CCA T-3'-Fluorescein; 5'-LCRed640-CGC ACA TCT CCG CAA ATG TAG AGG-3'-phosphorylation). One microgram of RNA was reverse transcribed for $30 \mathrm{~min}$ at $42^{\circ} \mathrm{C}$ (cDNA-synthesis), followed by $5 \mathrm{~min}$ at $95^{\circ} \mathrm{C}$ (enzyme denaturation) using $1 \mu 1$ $(0.125 \mu \mathbf{M})$ of oligo-dT-primer (TaKaRa RNA PCR Kit (AMV) ver. 2.1, Kyoto, Japan). The reaction was immediately put on ice and stored at $-20^{\circ} \mathrm{C}$. PCR analysis was performed using standard protocols. Real time quantitative RT-PCR was undertaken using the Light Cycler from Roche Diagnostics GmbH. Using this, it is possible to detect the amount of template online after each cycle of PCR amplification. Therefore, in addition to the two amplification primers, two further template-specific oligonucleotides, which were fluorescentlylabeled according to the FRET-principal (Light Cycler-Fast Start DNA Master Hybridization Probes Kit, Roche Diagrostics GmbH, Germany), were included in the PCR reaction. As a standard reaction, cDNA corresponding to $10^{5}, 10^{4}, 10^{3}$, or $10^{2}$ copies of total RNA from each sample was examined. Subsequently, cDNAs from different samples were analyzed, each corresponding to $250 \mathrm{ng}$ reverse transcribed, total RNA. To determine the absolute copy number of the target transcript, a cloned iNOS plasmid was used to generate a standard curve. The plasmid DNA was purified according to the manufacture's instructions(Nihon Gene Research Lab's Inc, Miyagi, Japan). The copy numbers for all unknown samples were obtained from the standard curve automatically. The cycling steps were as follows : one cycle of $95^{\circ} \mathrm{C}$ for $10 \mathrm{~min}$; followed by 40 cycles of $95{ }^{\circ} \mathrm{C}$ for $10 \mathrm{~s}$; $62^{\circ} \mathrm{C}$ for $15 \mathrm{~s}$; and $72^{\circ} \mathrm{C}$ for $9 \mathrm{~s}$.

\section{Statistical examination}

All values were expressed as means \pm S.D. Student's $t$ test were used to analyze for significant differences. A P value of less than 0.05 was considered to be significant.

\section{Results}

\section{ESR signal of the remnant liver}

The $\left[(\mathrm{MGD})_{2} \mathrm{Fe}\right]-\mathrm{NO}$ complex gave a characteristic 3 peak spectrum (Fig. 1) and the height of the first peak was measured. The NO intensity started to increase at $36 \mathrm{~h}$ after the partial hepatectomy and peaked at $72 \mathrm{~h}(48.4 \pm 5.4 \mathrm{~mm})$. The NO intensity in operated animals at $36,48,72$, and $96 \mathrm{~h}$ was significantly higher than that of the sham-operated ones $(P<0.05)$. The sham-operated animals at each time showed a constant NO intensity (30 $\pm 3 \mathrm{~mm}$ ) (Fig. 2). In the animals ( $72 \mathrm{~h}$ models) which were pre-treated with L-NAME (4 $\mathrm{mg} / 20 \mathrm{~g}$ and $2 \mathrm{mg} / 20 \mathrm{~g}$ mice weight) at $24 \mathrm{~h}$ after partial hepatectomy, the NO${ }^{\circ}$ intensity 


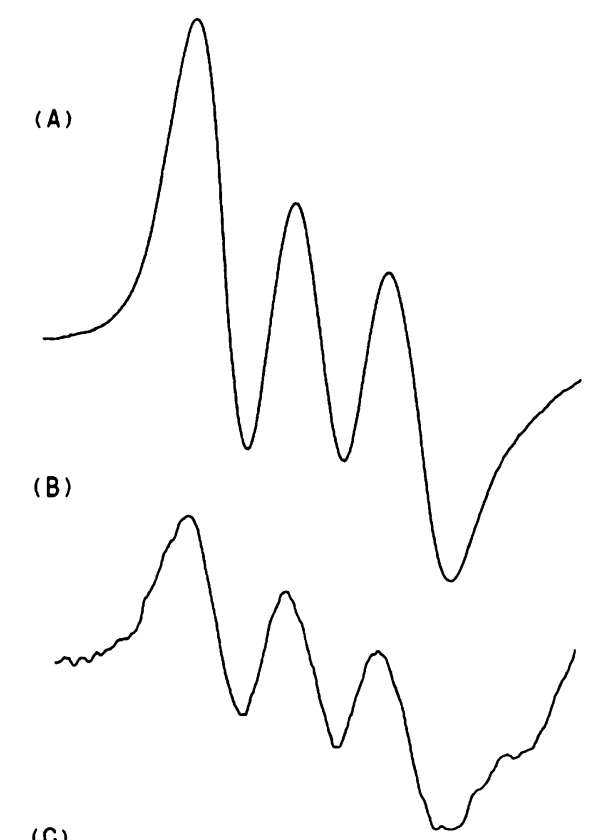

(C)

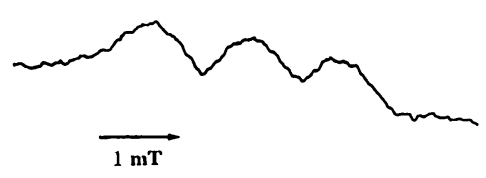

Fig. 1. ESR spectra of $\left[(\mathrm{MGD})_{2} \mathrm{Fe}\right]$ NO (a characteristic 3 line spectrum) in mouse liver. (A) Control: NOR-3 (ethyl-2-[hydroxyimino]-5-nitro-3-hexeneamide : NO ${ }^{\circ}$ generator) was trapped with $(\mathrm{MGD})_{2} \mathrm{Fe}$ in the control liver. (B) $72 \mathrm{~h}$ after hepatectomy. (C) $72 \mathrm{~h}$ after partial hepatectomy which had been injected at $24 \mathrm{~h}$ with L-NAME ( $4 \mathrm{mg} / 20 \mathrm{~g}$ mice weight).

was a significant difference between $72 \mathrm{~h}$ operated group (Fig. 3 ). There was a significant difference between the L-NAME $(4 \mathrm{mg} / 20 \mathrm{~g}$ mice weight $)$ treated and sham operated groups at $72 \mathrm{~h}(P<0.05)$. However, there was approximately the same NO ${ }^{\circ}$ intensity between the L-NAME $(2 \mathrm{mg} / 20 \mathrm{~g}$ mice weight) treated and the sham-operated groups at $72 \mathrm{~h}$ (Fig. 3).

\section{$R T-P C R$}

To investigate the expression of iNOS mRNA in the remnant liver at each time point, four mice in each group were measured. Quantification was performed by real time PCR product analysis using two labeled hybridization probes and light cycler technology. The absolute copy number of iNOS mRNA increased at 72 and $96 \mathrm{~h}$ after partial hepatectomy. The highest level of gene expression of iNOS mRNA was observed at $72 \mathrm{~h}$ after the operation $(P<0.05)$. However, in the group of animals which were treated with L-NAME $(4 \mathrm{mg} / 20 \mathrm{~g}$ mice weight) $24 \mathrm{~h}$ after the operation, iNOS mRNA expression was very low and the copy number was significantly less than that of the $72 \mathrm{~h}$ group $(P<0.05)$. 


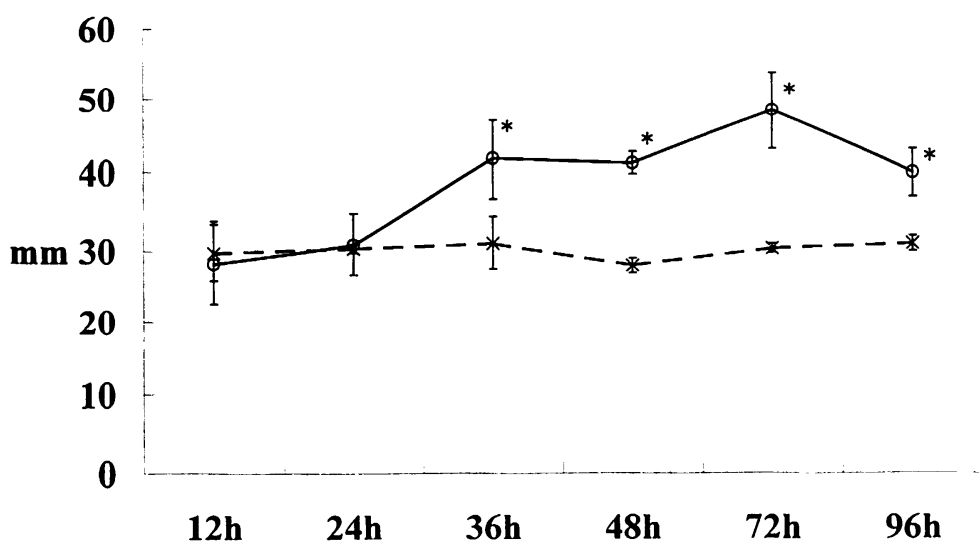

Fig. 2. Time-dependant ESR spectra. The first peak of intensity was measured at 12,24 , $36,48,72$ and $96 \mathrm{~h}$ after partial hepatectomy (circles and a solid line : $n=5$ ) and sham operation (cross and a dotted line : $n=3$ ) in mouse liver. Each point represents the mean \pm S.D. ${ }^{*}, P<0.05$ vs. sham operated group.

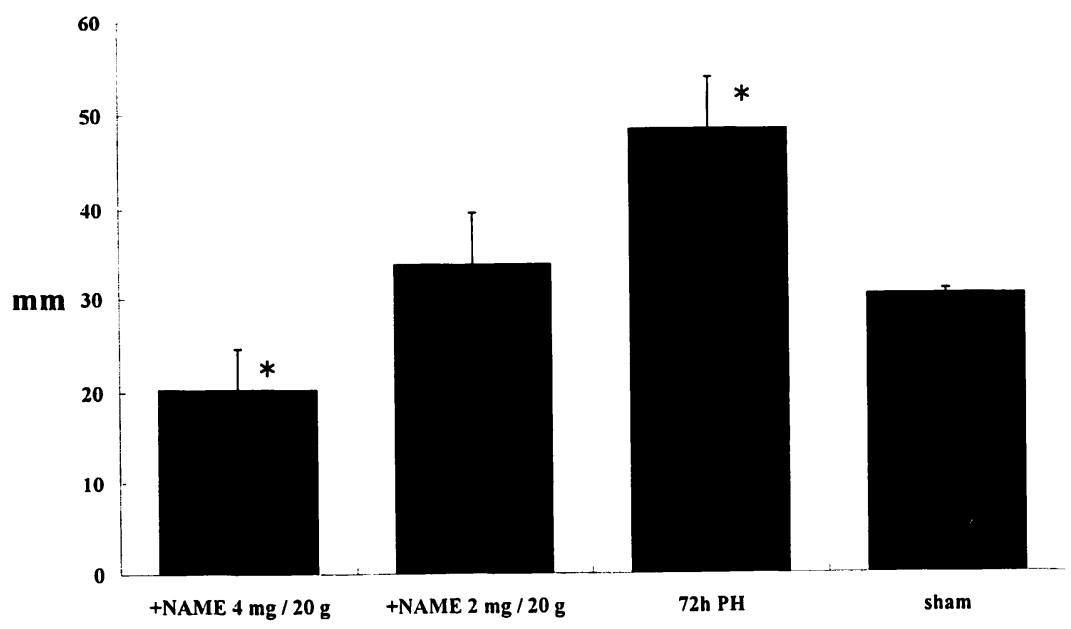

Fig. 3. ESR spectra of $72 \mathrm{~h}$ models after partial hepatectomy. Groups which were injected with L-NAME $(4 \mathrm{mg} / 20 \mathrm{~g}$ mice weight $)(\mathrm{n}=4)$ or L-NAME $(2 \mathrm{mg} / 20 \mathrm{~g}$ mice weight $)(n=4)$ at $24 \mathrm{~h}$ after partial hepatectomy, non treated hepatectomy $(n=5)$ and sham operation $(n==3)$. Each point represents the mean \pm S.D. ${ }^{*}, P<0.05$ vs. sham group.

\section{Discussion}

In the present study, NO ${ }^{\cdot}$ was detected in the mouse liver and moreover this is the first demonstration of time-dependent changes in $\mathrm{NO}^{\circ}$ after partial hepatectomy using an ex vivo spin-trapping method. NO' production after partial hepatectomy was inhibited by L-NAME, a competitive inhibitor of iNOS. Ex vivo ESR has been shown to be a useful and reliable tool to study $\mathrm{NO}^{\circ}$ generation in a real time ${ }^{11-15)}$. It is reported that $\mathrm{NO}^{-}$generation is 


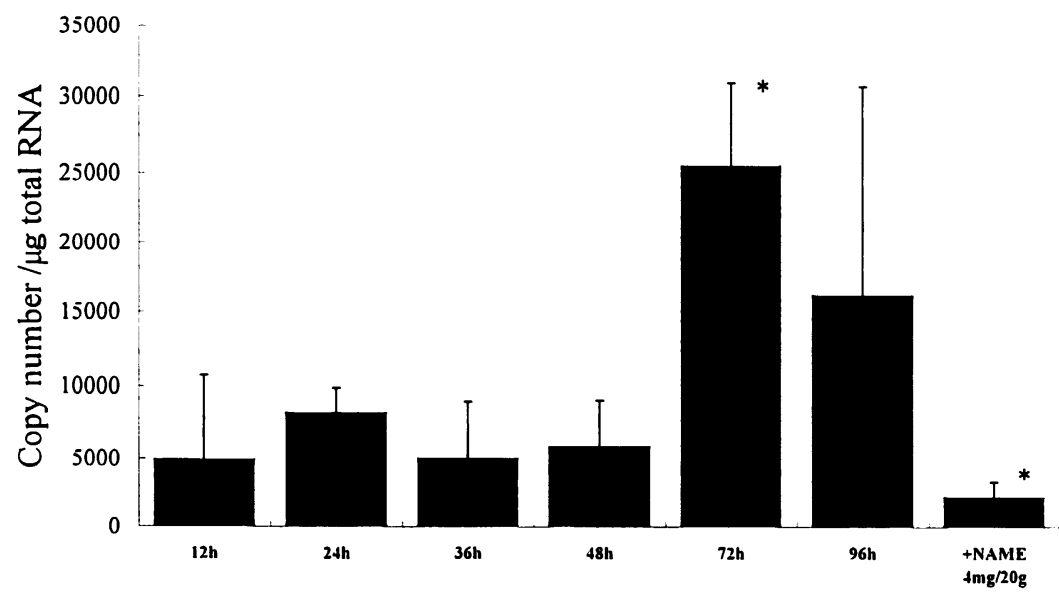

Fig. 4. iNOS mRNA expression after partial hepatectomy. Light cycler real time RT-PCR quantification is shown. Each time point, 12, 24, 36, 48, 72 and $96 \mathrm{~h}$ and the group injected with L-NAME $(4 \mathrm{mg} / 20 \mathrm{~g}$ mice weight $)$ group represents the mean \pm S.D. in four animals. ${ }^{*}, P<0.05$ vs. $24 \mathrm{~h}$ non treated group.

increased three times after partial hepatectomy in accordance with the periodicity of liver regeneration $^{11)}$. The first and second peaks of $\mathrm{NO}^{\circ}$ generation are seen at about $1 \mathrm{~h}$ and 4-12 $\mathrm{h}$ after hepatectomy respectively ${ }^{11}$. This coincides with the transition of the hepatocytes into the G1 phase of the cell cycle. The third peak of $\mathrm{NO}^{\circ}$ generation is observed between 30-37 $\mathrm{h}$ after the partial hepatectomy which coincides with the end of the first and the beginning of the second hepatic cell cycle and with the entrance of nonparenchymal cells into proliferation ${ }^{11,20)}$. We have shown that the peak of $\mathrm{NO}^{\circ}$ generation occurs at $72 \mathrm{~h}$ after hepatectomy (Fig. 2) and this suggests that the third rise of NO' generation is not only the second hepatic cell cycle and nonparenchymal cells proliferation. Soonho et $a l^{21}$ have shown that portal pressure is significantly elevated in portal branch ligation rats from day 1 after surgery and peaked on day 4. Sato et $a l^{22)}$ have shown that portal pressure after $70 \%$ partial hepatectomy peaks on postoperative day 3. At this time, it also appears that iNOS mRNA expression has increased to high levels (Fig. 4). We have been unsuccessful at detecting iNOS or other types of NOS's (endothelial and neuronal) by immunohistochemisty, therefore other studies to determine these protein levels are required.

It is shown that inflammatory cytokines such as interleukin-1 $\beta$ (IL-1 $\beta$ ) induce the expression of iNOS genes in primary cultured rat hepatocytes ${ }^{23,24)}$. Boulton et al $^{25)}$ reported that IL-1 is the major inhibitor of hepatocyte DNA synthesis present in nonparenchymal cells isolated from regenerating liver after partial hepatectomy. These findings strongly suggest that IL-1 plays a pivotal role in suppressing hepatocyte proliferation and terminating the surge of DNA synthesis induced after partial hepatectomy ${ }^{25)}$. Wang et $a l^{25)}$ have shown that the inhibitory effect of IL-1 on rat hepatocyte DNA synthesis is mediated by NO ${ }^{\circ}$ probably through iNOS gene expression. We have very recently shown in the mouse brain that iNOS immunoreactivity after global ischemia is reduced in IL-1 deficient mice as compared with wild-type mice, suggesting that endogenous IL-1 contributes to brain damage, and this acts through the release of $\mathrm{NO}^{\cdot}$ produced by $\mathrm{iNOS}^{27)}$. The previous and present studies strongly reinforce and extend prior observations on the inhibitory actions of IL-1 on hepatocyte 


\section{DNA synthesis acting through NO` production by iNOS expression.}

\section{References}

1) Francavilla A, Zeng Q, Polimeno L, Carr BI, Sun D, Porter KA, Van Thiel DH and Starzl TE : Small-for-size liver transplanted into larger recipient: a model of hepatic regeneration. Hepatology $19: 210-216$ (1994)

2) Court FG, Wemyss-Holden SA, Dennison AR and Maddern GJ : The mystery of liver regeneration. Br J Surg 89 : 1089-1095 (2002)

3) Kountouras J, Boura P and Lygidakis NJ : Liver regeneration after hepatectomy. Hepatogastoenterology 48 : 556-562 (2001)

4) Niiya T, Murakami M, Aoki T, Murai N, Shimizu $Y$ and Kusano $M$ : Immediate increase of portal pressure, reflecting sinusoidal shear stress, induced liver regeneration after partial hepatectomy. $J$ Hepatobiliary Pancreat Surg $6: 275-280$ (1999)

5) Schoen JM, Wang HH, Minuk GY and Lautt WW: Shear stress-induced nitric oxide release triggers the liver regeneration cascade. Nitric Oxide 5 : 453-464 (2001)

6) Muriel P : Regulation of nitric oxide synthesis in the liver. J Appl Toxicol 20 : 189-195 (2000)

7) Mann FC: The portal circulation and restoration of the liver after partial removal. Surgery 8 : 225-238 (1940)

8) Wang HH and Lautt WW : Evidence of nitric oxide, a flow-dependent factor, being a trigger of liver regeneration in rats. Can J Physiol Pharmacol 76 : 1072-1079 (1998)

9) Hortelano S, Dewez B, Genaro AM, Diaz - Guerra MJ and Bosca L : Nitric oxide is released in regenerating liver after partial hepatectomy. Hepatorogy 21 : 776-786 (1995)

10) Rai RM, Lee FJ, Rosen A, Yang SQ, Lin HZ, Koteish A, Liew FY, Zaragoza C, Lowenstein C and Diehl MA : Impaired liver regeneration in inducible nitric oxide synthase-deficient mice. Proc Natl Acad Sci USA 95 : 13829-13834 (1998)

11) Obolenskaya MY, Vanin AF, Mordvinctcev PI, Mulsch A and Decker K: Epr evidence of nitric oxide production by the regenerating rat liver. Biochem Biophys Res Commun 202 : 571-576 (1994)

12) Komarov A, Mattson D, Jones MM, Singh PK and Lai CS : In vivo spin trapping of nitric oxide in mice. Biochem Biophys Res Commun 195 : 1191-1198 (1993)

13) Quaresima V, Takahara $\mathbf{H}$, Tsushima $\mathbf{K}$, Ferrari $\mathbf{M}$ and Utsumi $\mathbf{H}$ : In vivo detection of mouse liver nitric oxide generation by spin trapping electron paramagnetic resonance spectroscopy. Biochem Biophys Res Commun 221 : 729-734 (1996)

14) Fujii $\mathbf{H}$, Koscielniak $J$ and Berliner $L J$ : Determination and characterization of nitric oxide generation in mice by in vivo L-Band EPR spectroscopy. Magn Reson Med 38 : 565-568 (1997)

15) Komarov AM and Lai CS : Detection of nitric oxide production in mice by spin-trapping electron paramagnetic resonance spectroscopy. Biocm Biophys Acta 1272 : 29-36 (1995)

16) Lai CS and Komarov AM : Spin trapping of nitric oxide produced in vivo in septic-shock mice. FEBS Lett 345 : 120-124 (1994)

17) Nathan C and Xie QW : Regulation of biosynthesis of nitric oxide. J Biol Chem 269 : 13725-13728 (1994)

18) Nussler AK, Di Silvio M, Billiar TR, Hoffman RA, Geller DA, Selby R, Madariaga J and Simmons RL: Stimulation of the nitric oxide synthase pathway in human hepatocytes by cytokines and endotoxin. J Exp Med 176 : 261-264 (1992)

19) Higgins GM and Anderson RM : Experimental pathology of the liver: I. Restoration of the liver of the white rat following partial surgical removal. Arch Pathol 12 : 186-202 (1931)

20) Shiratori Y, Ohmura K, Hikiba Y, Matsumura M, Nagura T, Okano K, Kamii K and Omata M : Hepatocyte nitric oxide production is induced by kupffer cells. Dig Dis Sci 43 : 1737-1745 (1998)

21) Um SH, Nishida O, Tokubayashi M, Kimura F, Takimoto $Y$, Yoshioka $H$, Inque $R$ and Kita $T$ : Hemodynamic changes after ligation of a major branch of the portal vein in rats : comparison with rats with portal vein constriction. Hepatology 19 : 202-209 (1994)

22) Sato Y, Koyama S, Tsukada K and Hatakeyama K: Acute portal hypertension reflecting shear stress as a trigger of liver regeneration following partial hepatectomy. Surg Today 27 : 518-526 (1997)

23) Tu W, Kitade $\mathbf{H}$, Kaibori $M$, Nakagawa $M$, Inoue $T$, Kown $A H$, Okumura $T$ and Kamiyama $Y$ : An enhancement of nitric oxide production regulates energy metabolism in rat hepatocytes after a partial hepatectomy. J Hepatol 30 : 944-950 (1999)

24) Geller DA, Nussler AK, Di Silvio M, Lowenstein CJ, Shapiro RA, Wang SC, Simmons RL and Billiar TR : Cytokines, endotoxin, and glucocorticoids regulate the expression of inducible nitric oxide synthase in hepatocytes. Proc Natl Acad Sci USA 90 : 522-526 (1993)

25) Boulton R, Woodman A, Calnan D, Selden C, Tam F and Hodgson H : Nonparenchymal cells form regenerating rat liver generates interleukin-1 $\alpha$ and $-1 \beta$ : a mechanism of negative regulatin of hepatocyte 
proliferation. Hepatology 26 : 49-58 (1997)

26) Wang $Z$, Wang $M$ and Carr BI : The inhibitory effect of interleukin $1 \beta$ on rat hepatocyte DNA synthesis is mediated by nitric oxide. Hepatology 28 : 430-435 (1998)

27) Mizushima H, Zhou CJ, Dohi K, Horai R, Asano M, Iwakura Y, Hirabayashi T, Arata S, Nakajo S, Takaki A, Ohtaki $H$ and Shioda S: Reduced postischemic apoptosis in the hippocampus of mice deficient in interleukin-1. J Comp Neurol 448 : 203-216 (2002)

[Received February 14, 2003 : Accepted February 19, 2003] 